\title{
'WAR AS REMEDY OR POISON': READING THE BLIND MAN'S GARDEN AND THE KITE RUNNER WITH A CRITICAL LENS OF MBEMBE'S NECROPOLITICS
}

\author{
Sara Iqbal Kakar ${ }^{1}$, Humaira Riaz ${ }^{2 *}$, Nayab Ahmad Khan ${ }^{3}$ \\ ${ }^{1}$ Graduate, City University of Science \& IT Peshawar Pakistan; ${ }^{2 *}$ Assistant Professor, City University of Science \& IT \\ Peshawar, Pakistan; ${ }^{3}$ Islamia College Peshawar, Pakistan. \\ Email: ${ }^{1}$ saraiqbalfcw.24@gmail.com, ${ }^{2 *}$ humairariaz@cusit.edu.pk, ${ }^{3}$ nayabahmadpmdc.34@gmail.com \\ Article History: Received on $10^{\text {th }}$ June 2021, Revised on $27^{\text {th }}$ June 2021, Published on $30^{\text {th }}$ June 2021
}

\begin{abstract}
Purpose of the Study: This study emphasizes the contribution of fiction in highlighting the American exercise of power around the world predominantly Pakistan and Afghanistan. It investigates how America has become a dictating body deciding the life and death of human beings mainly in South Asian developing countries.
\end{abstract}

Methodology: Being Qualitative, this study uses Eaglestone's (2000) close reading technique to analyze words and structure of the texts of Khalid Hosseini's The Kite Runner and Nadeem Aslam Khan's The Blind Man's Garden. It develops a descriptive thesis leading to construct arguments by drawing a theoretical framework from Mbembe's necropolitics (2003). Mbembe took his inspiration from Foucault's idea of bio-power. Modern narrative discourse on sovereignty and its relation to war is taken as the main subject of necropolitics. Mbembe's idea of sovereignty as an exercise to get control of the mortality of the enemy helps to interpret the texts via the close reading method.

Main Findings: This study evaluated two novels to assert that necropolitics by taking its four basic concepts, power, war, politics, and death was the actual controlling power of a country. It analyzed fictional characters to argue how individuals endured hardships because of the necropolitical exercise of America and Russia in Afghanistan. Mbembe's conception of necropolitics helps in understanding fiction.

Applications of this study: The present study has significant implications from both theoretical and interpretative perspectives. Necropolitics, originally a political notion is reworked in fiction, which asserts that using this concept, power relations, their roots, and exercise around the world can be explored in various fields. This study contributes to dismantling the latent necropolitics in the society represented in fiction. It elevates the social and political consciousness of the general public of South Asia, particularly Pakistan and Afghanistan. This study can be helpful in the field of psychology to popularize the notion of necropolitics in contemporary society.

Novelty/Originality of this study: Comparatively a new field, Necropolitics has been discussed in the fields of medical sciences and education. This study significantly highlights its existence in the field of literary studies. Fiction as a direct reflection of society helps in deconstructing the prevailing exercise of necropolitics in South Asian society. It is also helpful in raising the social and political consciousness of South Asian people.

Keywords: Necropolitics, War, Politics, Remedy, Fiction.

\section{INTRODUCTION}

The present study is conducted against the backdrop of the Afghan war. War characterizes a conflict between two political groups engaged in enmity and power control. Sovereign states impose armed incursions upon countries to exercise hegemony. The concept of war fundamentally carries evil designs leading to the worst consequences due to modern technological warfare. Wars are initiated because of ethnopolitical conflicts, religious controversies, and retributions. Revenge wars are irrational while religious wars are the longest and brutal (Jackson \& Morelli, 2009).

Soldiers on the battlefield are defined as "puppets" following orders and instructions by the state (Feltham, 2019). They are morally equal on both sides. In consideration of the war facts, it is an institution recognized by custom or law. War is also discussed as biopolitics; a complicated social theory by Michael Foucault (1991). It indicates a new component in power and knowledge technique; a complete subjugation of life to the sovereign state. Biopolitics decides life and death; however, it is also a shield to human life (Foucault, 1991). Mbembe further reworked the concept of biopolitics to evolve the notion of necropolitics in the milieu of Black Racism. Mbembe, of a black origin himself, introduced necropolitics drawn upon Foucault's idea of biopolitics. Achille Mbembe, a supporter of 'francophone critical theory', theorized the lineage of the contemporary world, which was besieged by disparity, militarization, antagonism, and terror accompanied with re-emerging nationalist, racist and fascist mindsets 'determined to exclude and kill' (Mbembe, 2003). He delineated how democracy started surrounding itself with its dark side more dominantly. Mbembe called it the 'nocturnal body' founded on fear, violence, desire, and relations; the dominant characteristics of colonialism. Consequently, the shift harmed the essence of democracy, eroding its core values, and ideals it celebrated. War, thus appeared sacramental in the contemporary world as 'a conception of sovereignty' operating by obliterating all those deemed state enemies. Mbembe's dreadful diagnosis was modelled on the post-Foucauldian concept of biopolitics, war, and race. He also viewed Fanon's conception of 'care' as a communal susceptibility for discovering novel formations by human beings excelling in humanism. Such novel notions encounter "the other" who is not meant to be excluded but looked at as one 
building an impartial sane world (Mbembe, 2003). Despite Fanon's social, political, and economic struggles for Africa; Mbembe (2003) repudiated Fanon's depiction of colonized Africa. He proposed Necropolitics as an appropriate modality in which modern states functioned, as the preservation of life, was no longer the dominating function of control. It studies the intersection between living death and the death world. Conceptualization of Mbembe's notion of necropolitics in the contemporary world, America appears to play a substantial role in the exercise of power around the world noticeably in the affairs of the Third World countries. Terrorism has grown as a serious menace in the post 9/11 world; the biggest 'boomerang', providing America reasons to intrude and invade countries. However, on the surface, America seemed to control the diminutive and deprived social, economic, and political state of affairs in South Asian countries.

The social, economic, and political state of affairs of South Asian countries finds reflection in contemporary fiction. History in the contemporary world is tiresome and appalling to articulate the war scenario most of the time. Thus, fiction becomes a promising and essential medium to record and articulate the self-assumed right of authorities for enslaving others and uncovering various forms of political power or aggression. South Asian writers express it by narrating tales of their homelands and their people. Pakistani writers Nadeem Aslam Khan and Afghani writer Khalid Hosseini have extraordinarily reproduced common life through fiction. Nadeem Aslam'sThe Blind Man's Garden and Khalid Hosseini's The Kite Runner narrate the aftermaths of the Afghan War in the backdrop of 9/11 attacks on World Trade Center USA, Soviet and US invasion of Afghanistan. South Asian society is dominated by colonial and Western capitalism for almost half a century or more. The domination is exercised through killing, bloodshed, and war. They implement social, political, and economic policies to establish their control over the territories. This can be viewed as American colonial rule in the south Asian countries.

Delimited to the analysis of The Kite Runner and The Blind Man's Garden, the present study contributes to the existing research by incorporating the political lens of necropolitics in fiction. It not only dismantles the latent necropolitics within the society but also elevates the social and political consciousness of the general public of South Asia, particularly Pakistan.

\section{PROBLEM STATEMENT}

Terrorism is a serious menace to the world. America, announcing its sovereignty, has taken a self-assumed responsibility to deal with and eradicate terrorism by force, however, it appears to have planned control over the diminutive and deprived countries in the Asian region. The present study has encountered this problem for discussion via fiction, which reflects the necropolitical policies of America in Pakistan and specifically Afghanistan.

\section{RATIONALE OF THE STUDY AND OBJECTIVES}

The concept of war is evil and it has become worst with the emergence of modern technology. Slavery and metaphoric importance to the body of a suicide bomber relate closely to the brutal necropolitical system, which counts on death as a remedy. The present study discusses power, politics, war, and death in the selected novels articulating fear of death as one of the most important apparatus of war. Thus, it explores how fiction depicts the lives of fictional characters imagining death as the biggest fear in life, which paves the way for war. Necropolitics offers a useful lens to analyze the selected novels and highlight certain political issues, which individuals encounter globally. The concept helps to explore the power relations, their roots, and exercise around the world.

\section{LITERATURE REVIEW}

Politics as an inevitable facet of human life, exercise on human lives with an increase in the development of science and technology. A contemporary form of politics in the contemporary world is necropolitics or 'nocturnal body' which is 'molecularly equipped' to remain engaged with the world of death (Emerson, 2019). The world of living death and death world is similar. In both cases, death is the central factor. Either one is living in harsh circumstances or tending to fall into savage conditions, the position and situation of the society remain the same. To add more, Durrant (2018) gives a new perspective of power to necropolitics asserting necropolitics as the utmost form of biopolitics. Devoid of any aspect of positivity, necropolitics appears in the extreme form of violence. It leads to the annihilation of the population in any society (Durrant, 2018). The roots of biopolitics lie deep in racism, which creates division among people based on classes. There have been "shifts and overlaps" between biopolitical and necropolitical power (Salih \& Kraidy, 2020).

Mayblin (2019) pronounces that necropolitics governs through death, which occurs in the form of slow violence done by the state (Mayblin, 2019, p. 5). Necropolitics produces 'stress, anxiety and shame' (Mayblin 2019). Such violence brings psychological problems to human beings. Christodoulou (2017) draws upon Baudrillard's philosophy of death and defines necropolitics as "life and death equivalent in the indifferent fatality of survival". Wars are based on religion, revenge, ethnic groups for example 'the crusaders' and '30-year war'. Hitler wanted the dominance of his ethnic group by getting rid of all other ethnic groups (Jackson \&Morelli, 2009). Scholars have also addressed the moral equivalency of soldiers on both fighting sides emphasizing that combatants are 'human instruments' in the hands of the state, thus 'morally equals' (Feltham, 2019). Drones as an agent of necropolitics in modern war strategy with particular reference to the Afghan war demonstrate conflicting arguments about the validity and use of autonomous killing machines. The antidrone agents believe that this "inhumane and unjust" (Allinson, 2015). 
Necropolitics as an exertion of biopower depends on Foucault's idea demonstrating 'the link between necropolitics and biopower' for destroying the "unhealthy populations" (Allinson, 2015). Debates to determine racial inferiority and the unhealthy population seem the self-assumed duty of the colonial and imperial powers outlining their prejudices to undermine humane sentiments of co-operation and co-existence. Commercialization of politics, including politics of everyday life, involves the reproduction of patriarchal, gender, class, and race relations in a new form. "Patriarchy is not gone; it has been modernized, and marketized. All human interactions and institutions, including markets, are gendered" (Charkiewicz, 2009). Gender and gender relations have become a matter of power exercise. Social factors are responsible for such conflict in the societies leading to war and death.

Quinan and Thiele criticized a necropolitical lens of the dreadful historical event in a film, which cinematized hundreds of people dying in a shipwreck to show the European policy of letting die. Necropolitics, thus, uncovers certain bodies cultivated for life are deemed as 'productive' and 'lawful' and non-subjects branded as 'illegitimate' or 'illegal' (Quinan \& Thiele, 2019). The state protects those who are useful for it. Others who are not profitable for the state are compromised. It is a pre-planned game of power and control. Necropolitics hence is not limited to politics, war, power, and death only; it also encompasses gender discrimination, racism, drone attacks, mental diseases, and feminism. Jansen mentions Mbembe's concept of "modern suicide bombers in the Middle East" (Jansen, 2020). Member proposes two contradictory ideas of suicide. 'logic of martyrdom' and 'logic of survival' (Mbemebe, 2013), as cited in (Jansen 2020). In the 'logic of survival', the ultimate goal of a person is to preserve one's own life even if it is at expense of the life of others. However, in the 'logic of martyrdom,' the death of a person is fused with the willingness of taking the enemy along. Necropolitics is equally significant for the "study of landscape, memory, and affects it helps conceptualize that decisions to either encourage or deny territorialized effect are political acts with clear political consequences" (Bednar, 2013). The present study uncovers how fictional characters play the politics of power, war, and death. It also illustrates the legitimate existence of necropolitics in fiction, which is instrumental in revealing the history of necropolitical practices witnessed in the colonial and post-colonial era.

\section{METHODOLOGY}

Qualitative in nature, this study uses Eaglestone's (2000) close reading technique to analyze Khalid Hosseini's TheKite Runner and Nadeem Aslam Khan's The Blind Man's Garden. It offers new insight into fiction by drawing the theoretical framework from the critical lens of Mbembe's necropolitics (2003). Mbembe's necropolitics is "the ultimate expression of sovereignty resides, to a large degree, in the power and the capacity to dictate who may live and who must die" (Mbembe, 2003). Life is faulty only when death takes it hostage. It "exists only in bursts and in exchange with death" (Mbembe, 2003). The present study adopts its framework by merging the concepts of Foucault, Fanon, and Mbembe to investigate the idea of biopolitics as a structure enabling necropolitics. It focuses on the psychological traumas and tragedies of the characters by closely examining the differences of the necropolitical policies of West and East and reasons to unravel if war is a remedy or poison.

\section{RESULTS AND DISCUSSION}

Necropolitics is the exertion of power in the political paradigm of human life. One of the significant effects of necropolitics is that it needs a leader to rule. It is not only the exertion of death on the 'other' but it also forces people to live a life like death; life death. Such as war, slavery, social and economic subjugation through colonization, and contemporary globalization, which has formed mutant colonialism, which is digitally controlled through technology. The present study used four basic concepts of necropolitics; power, war, politics, and death to analyze fiction. It argued how individuals endured the necropolitical exercise of America and Russia in Afghanistan. A traumatic situation that brings poor countries under the influence and control of powerful states categorize these as Third World Countries by the West. As in opposition, a rebellion force is established with a purpose to protect its people. The bloodshed of innocent people in the disguise of redemption and development develops detestation in the hearts of Muslims. A necropolitical state decides who may live or must die. It plans destructive actions leading to terror formation for finding a passage through underdeveloped countries. Social and economic deprivation of Third World Countries make life a symbol of torture, and death becomes the harbinger of peace. War deranges local people in so many ways for example ethnic cleansing with machine guns massacring people. Necropolitics instigates an inferiority complex. Feelings of being a useless creature on earth create a huge burden on human psychology, which compels them to commit suicide. Death rates increase day by day because necropolitics encourages the deployment of weapons of mass destruction. Hence, a dead world is created. It mostly happens to poor people for example belonging to Palestine and South Africa controlled by necro power exercised by sovereign authorities.

The study focuses on Nadeem Aslam Khan's The Blind Man's Garden and Khalid Hosseini's The Kite Runner to explore the presence of necropolitics exercised by the dominant nations. The Blind Man's Gardennarrates the story in the aftermath of the wars through the lives and experiences of the common people. It shows people living among bombings, terrorism, torture, disappearance, and barbarism. Power, war, politics, and death are the main factor influencing the lives of fictional characters. The main character in The Blind Man's Garden, Major Kyra demonstrates the best example of exerting necro power on people. He has his justification for doing so. He leaves the military and removes the title 'major' from his name. He also demonstrates his anti-disposition of the Pakistani government alliance with America and the West for helping and supporting the superpowers as the superpowers design to obliterate Pakistan. At this point of the 
novel, the scene of the World Trade Center is reenacted. Kyra calls this attack a 'conspiracy' (Aslam, 2013). Previously associated with armed forces, he is trained with a disposition to raise questions. Hence, he plays the politics of death. No more a military man, he explicitly claims to know the policies devised by the military and the government for the benefit of their own country. However, Kyra shows anger at the Pakistani army and ISI for abandoning Afghanistan. It can be assumed that the government of Pakistan is under the control of the necropolitical state that is America. The character of Kyra represents rebellion as he resigns his military because of the reasons that Pakistan itself is under American pressure. West categorizes the poor countries as Third World under its control and as a reaction, the West is opposed by "militia economies" (Mbembe, 2003). It is a force made by common people with a purpose to defend its people. Therefore, characters like Kyra are the construct of a necropolitical system. He is not born rebellious but circumstances have transformed him so. Kyra wants power in his hands.

Necropolitics originates terrorist groups. In The Blind Man's Garden, the terrorist groups in Pakistan ask the government to accept their demands; however, the government refuses to do so as it is under American pressure. Kyra predicts that "Bombing the church or the Christian school will not achieve anything" (Aslam, 2013).

Twenty or thirty Pakistanis, be they Christian or Muslim, dying in an explosion in Pakistan isn't going to matter at all; neither our government nor anyone in the West will care about it (Aslam, 2013).

Kyra prepares young boys in the ardent spirit for suicide bombing. Bodies of these suicide bombers transform into a weapon to destroy the enemies without even thinking or questioning. The bomber searches his target everywhere (Mbembe, 2003). Such individuals are victims of inferiority complex. This huge burden of being a useless creature on earth compels them to commit suicide (Margulies, 2019). Kyra exerts power over people by the fear of death. He justifies his hatred towards the Pakistani government and America as killing innocent people is not a solution to the problem. The bloodshed of innocent people develops detestation in the hearts of Muslims. Kyra argues with Rohan about America and its intentions of bombing Pakistan in case Pakistan did not help them in fighting al-Qaeda and Taliban, 'they would bomb us back to the Stone Age' (Aslam, 2013). America overtly announces its power to the world for being capable of turning the tables. Thus, America as a necropolitical state dictates 'who may live or who must die (Mbembe, 2003). People like major Kyra are born and produce terrorists because of the imposed wars. When Kyra locks down the Christian school, his student Ahmad requests the commissioner of Pakistan for help and he refuses to say the government cannot, "influence the Americans to ask them to release captive, or withdraw from Afghanistan, that America is too big and too wounded at the moment for Pakistan not to obey it" (Aslam, 2013). Such terror formation reflects, 'Terror and death are at the heart of each' (Mbembe, 2003). For people like Kyra 9/11 bombing is planned to find a way through Pakistan and Afghanistan.

Another character, Mikal becomes the prisoner of a warlord who cuts off his index fingers of both hands and hangs them to a doorframe with many others as terror symbols. Mikal works hard for the fear of the warlord who beats him to death "but then worked hard to death was another fear" (Aslam, 2013). Manipulative ways of selling the prisoners to Americans is another plan of America reflected in the novel. Mikal has been told to steal the prophet's cloak from a mosque. David, an American investigator, asks Mikal his name, family, and identity but Mikal refuses to comply. David shows his anger for preferring "death" (Aslam, 2013). That is how the poor states under the control of the powerful are compelled to choose death as they have no other option. For them life denotes torture, and death becomes the harbinger of peace. Death is a 'release from the terror and bondage' in a necropolitical prospect (Mbembe, 2003). Necropolitics as a supreme form of biopolitics tends to multiply the killings of people.

The novel reflects the American disposition of power. David, an American representative, after torturing Mikal mentions different categories of violence endorsing Americans to be 'civilized' beings, which illustrates the irony of the situation (Aslam, 2013, p. 208). Through "slow violence"; the worst violence produces psychological problems, Mikal is threatened to cooperate (Mayblin, 2019). Akbar, Mikal's friend in an American prison, provides refuge to Mikal in his home South Waziristan and tells Mikal to be restful as he is wanted by the Americans for shooting two of their soldiers. "The Pakistani military is helping the Americans hunt down al-Qaeda heroes" (Aslam, 2013). If given a necropolitical lens, it may be assumed that Pakistan is serving an American purpose. Terrorized by the sovereign state, Pakistan starts an operation against al-Qaeda and the Taliban in Afghanistan as "terror is a defining feature of both slave and latemodern colonial regimes" (Mbembe, 2003). Death is instrumental in gaining control. Though necropolitics is limited to mass killing and the use of devastating technologies, it results in a "political despair" (Leshem, 2015, p.34).

Khalid Hosseini's The Kite Runner narrates the Soviet invasion of Afghanistan and dearth of the ethnic minorities. The character of Amir is focused on illustrating necropolitics in the sequence of events. Amir, the narrator, and protagonist of the novel is not a completely sympathetic character probably because of his serious mistakes in life. He at times shows contradictory feelings for his father and friend Hassan. His character transforms and he grows into a selfless adult from a selfish child. War changes his life and takes refuge in a strange country. Being silenced on the sexual abuse of Hassan, he remains perturbed and confused. His guilt keeps him anxious as Hassan has always been a sincere friend to him. Family background and religious beliefs discriminate them from each other. Hassan faces racial bias in public for his religion and Hazara cast as Hazaras are considered a 'disgrace' to Afghanistan. 
Monarchy ends in Afghanistan on 17th July 1973 when the king of Afghanistan, Zahir Shah is overthrown by his cousin Daoud Khan. Amir and Hassan are children at that time unaware of the word republican established for Afghanistan. Feminicide, a sex-based revulsion, generally defined as a deliberate assassination of women or girls only because they are females, directly mirrors the existence of necropolitics in any society. Women are put to excessive scrutiny to challenge their lives and eventually put to death. Avila (2012) confirms in his study that necropolitics specifically relates to the 'femicide and terror formation (Avila, 2012). The chain of violence and patriarchy is reduced by focusing on the construction of women as equal partners. However, the decision of death is usually taken by the elders (Ahmetbeyzade, 2008). Necropolitics of the tribal areas views the victim of honour killing as a carcass without attaching any emotions to it (Ahmetbeyzade, 2008). In addition to this, the debate on the trail of feminity through an aggressive act of death is more aggravated by the 'the wars of interpretation'. It promotes how the deceit is manufactured by the powerful to shame and vilify the victim by violating their sacrifice of life. Thus, necropolitics has opened up a way for speaking about 'femicides under the social, political, and economic context (Avila, 2012). The new understanding of necropolitics allows us to question this authority of allotting meaning to someone's death for malicious personal narratives. Speculation about women's rights and modern technology grows more and people start enjoying a comparatively liberal life. However, the charm is short-term. The fall of Kabul in 1979 when Amir is sixteen years old only, creates an atmosphere of distrust. Conspiracy brings the "muzzle end of a Kalashnikov" (Hosseini, 2003). The Soviet Union wanted a socialist government; however, the massacre as a result of the war was self-indicating. Politics is 'powerseeking. It "has its laws but the statesmen must apply it" (Sartori, 1973). It knows the art of amending laws to suit its purpose.

Living in America is not a charm for Amir as he lived a luxurious life in Kabul. He is psychologically taken in by Afghanistan. "For me, America was a place to bury my memories" (Hosseini, 2003). His beautiful memories in Wazir Akbar Abad are overshadowed by psychological trauma resultant from the Soviet invasion and his exile from Afghanistan (Sorenson, 2020). It is micropower that influences the social and mental behaviour of individuals. Hence, memories of Hasan's molestation and Amir's silence create a vacuum in his life. Moreover, he is startled to see post-war Kabul; "now a city of harelipped ghosts" or "death worlds" (Hosseini, 2003; Lamble, 2014). Afghanistan funnels into a world of death. Amir compares it to America; "Some places with no ghosts, no memories, and no sins" (Hosseini, 2003). Exercising "necropolitical sovereignty over memory in public landscapes" involves the deployment and display of the power for controlling "those spaces to facilitate some acts of remembrance and to obstruct or deny others" (Bedner, 2013, p. 341). Amir resolves to go back to Afghanistan. America has one attraction for him; Soraya. "SorayaTaheri was a better person than me" (Hosseini, 2003).

A writer by profession, he prefers to write fiction but not history, a history that is his own. He denies it. He sometimes assumes that America makes him forget everything, however, it does not. He remembers the minute things about Kabul. He notices Baba's smile which he compares with 'skies of Kabul on the night" (Hosseini, 2003). He has every bit of Afghanistan in him when he is away in America.

The saga of necropolitics reflected in the narratives is dominated by the power of capitalist forces. The phenomenon of 'global capitalism' is managed by the 'logic of death" (Grzinic, 2012). Capitalist masters control the entire world as their puppet for benefitting a specific class whereas the rest of the people are restricted by the jeopardy of death. A strong construct between capitalism and necropolitics affects every aspect of human life. Culture, art, and traditions act as 'biopolitical machines' (Grzinic, 2012). Notwithstanding the wealth of Afghani people, America, the dictator state, forced its native people to run away from their land. Amir is the prototype of such circumstances portraying the wretchedness of the rich people of Afghanistan in the face of death. Hence, the novel reflects that America achieves its goals by exercising power through the terror of death. Amir, acquiring the status of Asian Americans is labelled as 'foreigners' and 'outsiders' (Bui, 2019). Biopower and micropower have overtaken the societies under control (Kwate \&Threadcraft, 2017). He returns to Pakistan to rectify his mistakes; a humble man unlike a boy or a young man in America. He "feels like a tourist in my own country" (Hosseini, 2003). It is because Afghanistan is in the hands of sovereign authorities', Taliban whose basic concern is with the 'material destruction of human bodies and population" (Mbembe, 2003). Though a reaction to the Soviet Union, the Taliban demonstrates atrocities in their own way. They are the 'militia groups' of Afghanistan fighting for their land.

Amir accompanies Farid on his way to Kabul on Rahim khan provision. Amir notices a vehicle driven by the Taliban. Farid scolds Amir for staring Taliban as they compel people to fight with them and when they fail in provoking someone, they start 'random violence' (Hosseini, 2003). Taliban wants to set their rule based on terror formation as Mbembe called it. "Terror is constructed as an almost necessary part of politics" (Meintjes, 2003). Terror is a key to exert power. Amir compares Kabul with a 'homeless and destitute' friend. (Hosseini, 2003). "They are born there, it matters little where or how; they die there, it matters not where, nor how" (Fanon, 1963). Power is a complex idea (Lazzarato, 2002). It is a "net like" thing, which is complicated as well as easy at times (Balan, 2010). Braidotti argues about necropolitics that we all suffer equally from all kinds of powers in our lives (Braidotti, 2009). We all are under the influence of power but the locations and allocations of power are different. In the contemporary world, it can be either in the form of racism, gender discrimination, technological interventions, and wars. The war game is one of the biggest ways to exert power. 
In Hosseini's The Kite Runner, Amir's main purpose is to bring Hassan's son Sohrab with him, handed over to a Talib who provides money for the orphanage in return. Farid and Amir are searching for the Talib and Amir finds out that the area is quite better than the rest of Afghanistan. Farid informs him that they are the people 'behind the Taliban'. He calls the 'real brains' (osseini, 2003). The Talib Amir meets was Aasef. He recognizes Amir and takes revenge on him. Sohrab is with him in feminine attire. Assef tells him that they are doing "ethnic cleansing" by going door to door and moving around with their machine guns massacring people.

Rahim Khan, an eyewitness to the war in Afghanistan, always appreciates Amir's stories. He is the only one who takes Hassan back to Kabul knowing the secret that he is a half-brother to Amir. Rahim kaka is very kind to Amir in his childhood but when Amir leaves for California, he is not seen in the novel. His character appears again when Amir returns to Pakistan on his call. A humble man, Rahim believes in equality. He is strictly against the double standards of Afghanistan. He knows every detail because he is there living in baba's house hoping that one day it will all be over and peace will be restored. Rahim kaka narrates shocking stories about the Afghan war. His perspective is different from media portrayals. He describes the Taliban as "they don't let you to be human" (Hosseini, 2003). Afghanistan, a battlefield for everyone, is taken over by the Northern Allies. They fight against the Taliban as well as the Soviet Union taking over Kabul between 1992 and 1996. Rahim kaka describes those days as one "practically needed a visa to go from one neighborhood to the other" (Hosseini, 2003). Pakistan is on the enemy list of northern allies because the Mujahideen are trained in madrasas of Pakistan who are sent to Afghanistan to help their Taliban brothers. Pakistan as a result suffers from both sides as America pressurizes Pakistan's military to start operations against the Taliban as they suspect Taliban in the tribal areas of Pakistan. The situation reflects that necropolitics is dominated by the powerful capitalist forces which affect every aspect of a system (Grizinic, 2012).

Modern technology such as drone attacks is the active agent of necropolitics; "the arrogation of the sovereign's right both to command death and to assign [lamentable] meaning to the dead" (Allinson, 2015). American warfare is a potential threat to the sovereignty of the country as well as for humanity. Rahim Khan highlights the political turmoil of Afghanistan telling Amir that the northern alliance has done more damage to Kabul than shorawi. It is because America is a strong ally to northern allies. America wants Russia to lose the war so that it itself invades. It all seemed a great design structured by the superpowers. Soviet exclusion puts Afghanistan in the hands of "Massoud, Rabbani, and the mujahedin" (Hosseini, 2003).

Our ears became accustomed to the whistling of falling shells, to the rumble of gunfire, our eyes familiar with the sight of men digging bodies out of piles of rubble. Kabul in those days Amir Jan, was as close as you could get to that proverbial hell on earth" (Hosseini, 2003).

Afghans live in "being in pain" (Mbembe, 2003). There is a colonial occupation "interrogation and beatings, curfews" is a normal routine for soldiers (Mbembe, 2003). Even they are not safe in their homes terrorized by rockets bombings in the air. Rahim Kakarecalls history "when the Taliban rolled in and kicked the alliances out of Kabul, I actually danced on that street" (Hosseini, 2003). People paid a huge price for war. No one walks out of their home because of the mines in the ground, especially in the fields. They do not come out and die of hunger. Or "there were body parts of children" (Hosseini, 2003). The complexity of the human community appears convincing when wars and the power-hunger game transcend continents. Hence, digital dynamics of the world domination reflect all superpowers are the control devices on Earth (Lirios, 2019).

Hassan and Amir share a history of Kabul where they grow up. "In Kabul, fear is everywhere, in the streets, in the stadium, in the markets, it is a part of our lives here Amir Agha" (Hosseini, 2003). This is the fear of death. War machines are made for the destruction of human bodies. People do not come out because of the fear of death. Necropolitics is therefore the 'work of death' (Flacks, 2018). Interestingly, necropower is not the only exertion of real death but its virtual warning guides the social and mental behaviors of individuals. The influence is widespread; however, the "sovereign power is never only physical. Apart from the psychological and moral subordination of the other", death remains as the only power (Sorensen, 2020). Many ideological and cultural wars are determined by the threat of death by the dominants.

Necropolitics attains power over the 'other'. This power is exercised by "monstrosity, trauma, murder and killing" (Gunduz, 2017). Life and Death correspond in indifferent "fatality of survival" (Christodoulou, 2017). Survival matters to war-affected people; however, death is a relief from grief-stricken life.

\section{CONCLUSION}

The present study adds substantially to our understanding of the four components of necropoloitics; power, war, politics, and death within the setting of selected Asian English fiction. Through the close reading analysis technique, the evidences quoted from the novels helped to comprehend Mbembe's conception of necropolitics in the milieu of the Afghan war. It concluded that war did not act as a remedy but poison for South Asian Muslim countries increasing honor killing, gender discrimination, education suppression, and the use of modern warfare. Necropolitics not only affected regions but it intensely influenced the lives of individuals transforming them into new beings; oppressors or suppressed. The study explored the portrayal of power order. Aslam's novels in the aftermath of the 9/11 attack exemplified 
America's rage after the attacks blaming Pakistan and Afghanistan. The world changed after that, and Muslims around the world particularly in America were suspected and seen involved in the conspiracy against America. Following the consequences, mujahedeen in Muslim countries emerged as an anti-American force to protect Muslims. The study also highlighted the representation of death-worlds through the extremism of the Taliban. The American claim that by intrusion in Afghanistan, it organized population, protected sovereignty, and systematized global order, shattered. Evidences from both the novels demonstrated that America used war as a tool for self-defense, which assisted its notion that war was a remedy for American survival and global peace. American defeat is announced unequivocally in its retreat from Afghanistan.

\section{LIMITATION AND STUDY FORWARD}

The study is delimited to the analysis of fiction focusing on the main characters. Its limitation clearly lies in the fact to access the writers for more vivid details. In the future, the study can be conducted to illustrate necropolitics reflected in fiction as well as visual media portrayals.

\section{ACKNOWLEDGEMENT}

Dr. Humaira Riaz is acknowledged to re-orient the entire study, its theoretical frameworks, and special attention to language. Ms. Sara Iqbal and Ms.Nayab Ahmad are acknowledged for their financial support. SaraIqbal laid the foundation of the present study.

\section{AUTHORS' CONTRIBUTION}

Sara Iqbal, M.S. in English, is the principal author. The research paper is based on her M.S. in English research thesis. Dr. Humaira Riaz supervised the M.S. research study. She is the corresponding author and has contributed to the theoretical framework, analysis, findings, and language editing. Nayab Ahmad Khan has contributed to the literature review part.

\section{REFERENCES}

1. Ahmetbeyzade, C. (2008, September 16). Gendering Necropolitics: The Juridical-Political Sociality of Honor Killings in Turkey. Journal of Human Rights, 7(3), 187-206. https://doi.org/10.1080/14754830802286095

2. Allinson, J. (2015). The Necropolitics of Drones. International Political Sociology, 9(2), 113-127. https://doi.org/10.1111/ips.12086

3. Avila, E. A. (2012). Conditions of (Im)possibility: Necropolitics, Neoliberalism, and the Cultural Politics of Death in Contemporary Chicana/o Film and Literature. University of California, San Diego.

4. Aslam, N. (2013). The Blind Man's Garden. London: Faber \& Faber.

5. Balan, S. (2010). M. Foucault's View on Power Relations. Cogito. Multidisciplinary Research Journal, 2, 5561.

6. Bednar, R. (2013). Killing Memory: Roadside Memorial Removals and the Necropolitics of Affect. Cultural Politics, 9, 337-356. https://doi.org/10.1215/17432197-2347018

7. Braidotti, R., Colebrook, C., Hanafin, P. (2009). Deleuze and Law Forensic Futures. London: Palgrave Macmillan. https://doi.org/10.1057/9780230244771

8. Bui, L. (2016). A Better Life? Asian Americans and the Necropolitics of Higher Education. In Critical Ethnic Studies: A Reader (pp. 161-174). Duke Univerity Press. https://doi.org/10.2307/j.ctv11hpkv8.11

9. Charkiewicz, E. (2009). A feminist critique of the climate change discourse. From Biopolitics to Necropolitics. Critical Current, 6, 18-25.

10. Christodoulou, M. (2017, january 12). To be dead is an unthinkable Anomaly: Reversed Necropolitics and the Death Imaginary. Sguardo - Rivista di Filosofia, 23, 127-137.

11. Durant, S. (2018). Creaturely Mimesis: Life After Necropolitics in Chris Abani's Song for Night. Research in African Literatures: Performances of Sovereignty in African Dictator-Fiction, 49, 178-206. https://doi.org/10 .2979/reseafrilite.49.3.11

12. Eaglestone, R. (2013). Contemporary Fiction in the Academy: Towards a Manifesto. Textual Practice, 7(27), 1096. https://doi.org/10.1080/0950236X.2013.840113

13. Emerson, R. G. (2019). Necropolitics: Living Death in Mexico. Cham, Switzerland: Palgrave Macmillan. https://doi.org/10.1007/978-3-030-12302-4

14. Fanon, F. (1961). The Wretched on the Earth. (C. Farrington, Trans.) Paris, France: Grove Weidenfeld.

15. Feltham, B. (2019). War, Peace and International Ethics. School of Politics and International Relation, 6.

16. Flacks, S. (2018). Law, necropolitics and the stop and search of young people. Theoretical Criminology, 24(2), 387-405. https://doi.org/10.1177/1362480618774036

17. Foucault, M. (1991). The Foucault Effect: Studies in Governmentality. (G. Burchell, C. Gordon, \& P. Miller, Eds.) Chicago: The University of Chicago Press.

18. Grzinic, M. (2012, September). Biopolitics and Necropolitics in relation to the Lacanian four discourses. Simposium Art and Research: Shared methodologies. Politics and Translation, 6-7.

19. Hosseini, K. (2003). The Kite Runner. London: Bloomsbury. 
20. Jackson, M., \& Morelli, M. (2011). The Reasons for Wars - an Updated Survey. In R. L. Chirstopher J. Coyne (Ed.), The Handbook on the Political Economy of War (p. 34). Department of Economics, Stanford University, California: Edward Elgar Publishing Limited .

21. Kwate, A., \& Threadcraft, S. (2018, April 20). Dying Fast And Dying Slow In Black Space: Stop and Frisk's Public Health Threat and a Comprehensive Necropolitics. Du Bois Review: Social Science Research on Race, 12(2), 535-556. https://doi.org/10.1017/S1742058X17000169

22. Lazzarato, M. (2002). From Biopower to Biopolitics. Pli: The Warwick Journal of Philosophy, 13, 112-125.

23. Lirios, C. G. (2019). Specification A Model For Study Of Biopolitics. Journal of Social Studies, 21(43), 128135. https://doi.org/10.19093/res9461

24. Leshem, N. (2015). "Over our dead bodies": Placing Necropolitical Activism. Political Geography, 45, 34-44. https://doi.org/10.1016/j.polgeo.2014.09.003

25. Mbembé, J. (2003). Necropolitics. Public Culture, 15, 11-40. https://doi.org/10.1215/08992363-15-1-11

26. Margulies, J. D. (2019). Making the 'man-eater': Tiger conservation as necropolitics. Political Geography, 69, 150-161. https://doi.org/10.1016/j.polgeo.2018.12.011

27. Lincoln, Y. S., \& Guba, E. G. (1994). Competing Paradigms in Qualitative Research. In N. K. Denzin, \& Y. S. Lincoln (Eds.), Handbook of qualitative research (pp. 105-117). Thousand Oaks, CA: Sage Publications.

28. Mayblin, M. W. (2019). Necropolitics and the Slow Violence of the Everyday: Asylum Seeker Welfare in the Post Colonial Present. Sociology, 54(1), 107-123. https://doi.org/10.1177/0038038519862124

29. Salih, A., Kraidy, M. (2020). Islamic State and Women: A Biopolitical Analysis. International Journal of Communication, 1933-1950.

30. Sartori, G. (1973). What is "Politics". Political Theory , 1(1), 5-26. https://doi.org/10.1177/009059177 $\underline{300100102}$

31. Sorensen, N. N. (2020). Governing through the mutilated female body : corpse, bodypolitics and contestation in contemporary Guatemala. In F. Stepputat (Ed.), Governing the Dead: Sovereignty and the Politics of Dead Bodies (pp. 11-221). Manchester University Press. 